\title{
Citizenship Education curriculum in Greece - beyond ethnocentric or eurocentric approach
}

\author{
MARIA FILIO TRIDIMAS \\ University of Piraeus \\ mariaphil.ed@gmail.com
}

\begin{abstract}
The issue of intercultural and citizenship learning has concerned scholars for a long time while subjects such as history, geography, civic and citizenship have been shaping young peoples' identity. Under migration pressures and the European Union's integration these subjects have been often challenged and transformed. In the case of Greece, subject's textbook topics on immigration and diversity have been promoting more ethnocentrism and eurocentrism. This paper presents those findings, and in so doing it explores the ways in which the Greek state's and the EU's intercultural education policy have impacted the specific school subject. It focuses on the Greek nation's identity formation, while discussing the country's response to the EU's calls for common policies in the area of intercultural and citizenship education. The last section of this essay provides new insights into the educators' tools to implement less ethnocentric and more inclusive curriculums and programs by exploring an extracurricular, online peer mentoring program that was initiated and implemented in Australia to foster intercultural awareness.
\end{abstract}

Keywords: Intercultural and citizenship education, online language programs, peer mentoring, eurocentrism, Greece, ethnocentrism.

\section{Introduction}

The issue of intercultural and citizenship learning has concerned scholars for a long time since subjects such as history, civic and citizenship etc. have been historically shaping and molding young people's education and identity as future citizens. 1 It is indicative that in Greece, the civic and citizenship subject is taught with the aim to create a strong sense of national identity by focusing on the country's history and cultural endowment, respected worldwide.2

In the European Union (EU), the Commission's recommendation is that the citizenship education subject is taught to: 'encourage students towards becoming active, informed and responsible citizens, able to take responsibility for themselves and their communities at the local, regional, national and international level'.3

\footnotetext{
1. Daniel Faas, "The Nation, Europe and Migration: A comparison of geography, history and citizenship education curricula in Greece, Germany and England," Journal of Curriculum Studies 43, no. 4, (2011): 471-492.

${ }_{2}$ Official Government Gazette, 2003; Daniel Faas, "Between ethnocentrism and Europeanism? An exploration of the effects of migration and European integration on curricula and policies," Ethnicities 11, no. 2, (2011): 163-183. ${ }_{3}$ European Commission/EACEA/Eurydice, 2017. Citizenship Education at School in Europe - 2017. Eurydice Report. Luxembourg: Publications Office of the European Union.
} 
However, nation states' socio-historical reasons at the interface of national identity, EU identity and migration strongly shape the subject's aims and the way intercultural learning is understood and implemented. Looking into the EU's and Greece's intercultural and civic and citizenship policies, it seems that there are challenges related to curriculum's ethnocentrism and/or eurocentrism in these subjects. These challenges are deeply rooted in each member state's notion of national identity and migration trajectory. Some could also be traced to the relationship between the member states and the EU, and the latter's role when developing policy in the intercultural and citizenship field.

This paper aims at presenting some key points related to the EU's and member states' intercultural and citizenship policy by providing insights and focusing on Greece. Research has indicated that the country's civic and citizenship curriculum 'veers between ethnocentrism and eurocentrism by marginalizing also topics relating to migration, 'otherness' and integration' 4 . Therefore, the essay discusses those findings by exploring the ways in which the state's and EU's intercultural and citizenship education policy have impacted the specific school subject in Lower and Upper Secondary School.

\section{Reforms for strengthening cultural and linguistic identity in Greece's multicultural society}

In Greece, education policy is centralised. Therefore, it is the Greek Ministry of Education and Religious Affairs ${ }_{5}(\mathrm{MoE})$ that is largely responsible for the country's education administration, its policies and procedures. Within this framework, the MoE exercises control over public schools, formulates and delivers policies, and administers the budget among others. The compulsory school system is divided into three stages: preschool, primary school and lower secondary school while upper secondary (from the age of 15) is non-compulsory.

The subject of civic and citizenship is taught across all schooling stages. In secondary school, the subject is offered with the aim to 'develop students culturally by strengthening their national and cultural identity, increasing their awareness of the nature and role of various groups they belong to, their readiness to accept diversity by developing young people's Greek identity and awareness based on Greek national and cultural heritage'.6 It is offered as a mandatory textbook-based and separate subject. As such, its objectives, content and learning outcomes are constrained within a separate subject boundary.7

The civic and citizenship subject was introduced in 2003. At the time, the Greek Ministry of Education attempted a shift in the area of education by promoting curriculum changes that reinforced the system's intercultural perspective and character. Under the General Principle of 'strengthening cultural and linguistic identity in a multicultural society' the Ministry initiated a series of reforms that integrated intercultural and European dimensions into the country's mainstream

\footnotetext{
${ }_{4}$ N. Palaiologou, and Daniel Faas, "How 'intercultural' is education in Greece? Insights from policymakers and educators." Compare: A Journal of Comparative and intercultural education 42, no. 4, (2012): 563-584; Faas, "The Nation," 471-92; Faas, "Between ethnocentrism," 163-83.

${ }_{5} \mathrm{MoE}$, abbreviation for Greek Ministry of Education.

6 Official Government Gazette, 2003; Faas, "Between ethnocentrism,” 163-83.

7 Official Government Gazette, 2003.
} 
educational programme by promoting respect for linguistic diversity, encouraging multicultural methodologies and introducing the relevant subject of civics. 8

The reforms aligned with the range of initiatives adopted by other states with an intercultural commitment. Their purpose was to review the "processes through which relations between different cultures were analysed and made explicit in school curricula'.9 By reforming the state's national curriculum and incorporating the European and intercultural dimension for compulsory education the aim was to strengthen diversity.10 This meant promoting changes that encouraged students to learn about: a) the cultural diversity via developing values of respect that combat racism and xenophobia; b) the international dimension via an understanding of contemporary cultural diversity related to international relations, migration and integration phenomenon; and c) Europe, European identity, peoples' cultural characteristics etc.11

The MoE's reforms in 2003 were of fundamental importance, since this was the second time the state recognised that Greece was a culturally diverse society. The first one was in 1996 the Greek state passed the Act 2413/1996 and introduced intercultural schools $_{12}$ for the education of young people with educational, social and cultural particularities [...]'.13 Until the early 1990s Greece promoted its own version of intercultural polices by accommodating diversity with implicit assimilation perspectives, rooted in its cultural 'homogenous' and monolingual environment.

It is also interesting to look at the country's migration trajectory, as it has also influenced Greece's approach to intercultural policy. Greece historically has been a sender country. However, it became more diverse in the 1970 s when many repatriates from Germany, USA, Australia, Canada and South Africa returned due to the country's democratisation process. 14 In the 1980 s, this repatriation was reduced in intensity, however shortly after the numbers of ethnic Greeks and immigrants from Southeast Europe and the former Soviet Republics increased. ${ }_{15}$ It was then, that the country initiated the term 'intercultural education' to (re)integrate the repatriates' children into Greek schools and Greek society.16 Following the fall of the Berlin Wall (1989), the arrivals increased even more.

Yet, the country's educational system was not prepared to integrate this population and facilitate meeting the children's needs.17 In fact migrant and 'remigrant' children's needs were ignored. If one examines the country's different periods of education policy enactment for the integration of pupils from different cultural backgrounds, then three

8 Faas, "The Nation," 471-92; Faas, "Between ethnocentrism," 163-83.

9 Marco Catarci, "Intercultural education in the European context: key marks from a comparative study,"

Intercultural Education 25, no.2, (2014): 95-104.

${ }_{10}$ Official Government Gazette, 2003.

${ }_{11}$ Catarci, "Intercultural education," 98.

12 In the Greek language the term is Diapolitismika Sxoleia. Additional view: A. Triandafyllidou and R. Gropas,

"Greek Education Policy and the Challenges of Migration: An Intercultural View of Assimilation," paper prepared for the EMILIE project (ELIAMEP, November 2007).

${ }_{13}$ Palaiologou and Faad, "How 'intercultural' is education, 563-584; Faas, "Between ethnocentrism," 163-83;

Triandafyllidou and Gropas, "Greek Education Policy".

${ }_{14}$ According to official statistical data the number of foreign workers in Greece approximated 6o,ooo. Additional view: George Markou, "Intercultural education in multicultural Greece", European Journal of Intercultural Studies 4, no. 3, (1993): 32-43.

${ }_{15}$ Michael Damanakis, “European and Intercultural Dimension in Greek Education”, European Educational Research Journal 4, no. 1, (2005): 79-88.

16 Markou, "Intercultural Education," 32-43.

${ }_{17}$ Paleologou, "Intercultural education," 317-29. 
distinct periods can be identified. The first was the 'Melting Pot' one. This period lasted from the 1970 s to the early 1980 s and was characterised by lack of real policies to address 'remigrant' or repatriate's children's needs.18

The second one, which took place in the 1980s, was known as the 'AssimilativeCompensatory' one. During this period, it was believed that 'remigrant' (co- ethnic returnees and ethnic Greeks) and migrant children ('foreigners') had to learn the Greek language intensively and immediately after their entry into the country. Towards that end, intensive Greek language learning courses were organised in separate classes to integrate as many children as soon as possible. 19 However, since teachers had no formal teaching experience in teaching Greek as a second or foreign language, separate responses and practices were adopted towards repatriated Greek students on the one hand and foreign migrant children on the other.20,21. Delving into the literature, the state's intercultural history demonstrates that this period became widely known as the 'deficit' period since it advanced 'identity sameness' (....). For students with Greek ancestry adaptation was easier, since they had some knowledge of Greek language, culture, history and/or religion, whereas for foreign students adaptation meant sacrificing their cultural identity.22

The third period of education policy enactment towards the integration of pupils from different cultural backgrounds was in the 1990s. This period, known as the 'compensatory-pluralistic' period was characterised by a shift from the 'education of the foreigners' model to 'Intercultural education.' 23 Broadly, this was the period when Reception classes/centers were re-established ${ }_{24}$ and intercultural schools were founded (Law 2413/96 on 'Greek Education Abroad, Intercultural Education and Other Provisions) on the basis of the 'multicultural characteristics exhibited in the Greek society'.25 In spite of the state's intentions, the reforms that were initiated by Law 2413/96, attracted severe criticism related to the country's intercultural restricted scope 26 and the country's inability to balance cultural diversity with social cohesion.

While the reforms in 2003 were an attempt to promote European and intercultural understanding in Greece, recent research focusing on the degree to which European integration and multiculoo74ural discourses have been intertwined in citizenship education curricula in Greece, has indicated that it 'veers between ethnocentrism and eurocentrism' and 'marginalises topics relating to migration, 'otherness' and integration'.27 Findings showcase that the civic and citizenship curriculum in Greece

\footnotetext{
18 Markou, "Intercultural Education," 32-43.

19 Markou, "Intercultural Education," 32-43.

20 Damanakis, "European and Intercultural Dimension," 79-88.

${ }_{21}$ This ingrained discrimination between migrants was demonstrated in the country's citizenship acquisition Acts as well.

22 Faas, "The Nation," 471-92.

${ }_{23}$ Damanakis, "European and Intercultural Dimension," $79-88$; Palaiologou and Faas, "How 'intercultural' is," $563-84$.

${ }_{24}$ Ministry of Education (1980) 818.2/z/4139/1980 \1; Markou, "Intercultural Education,” 32-43, Triandafyllidou and Gropas, "Greek Education Policy"; Damanakis, "European and Intercultural dimension," 79-88.

${ }_{25}$ D. Chalkiotis, General Secretary of Intercultural Education cited in Andreas M. Kazamias and Yiannis

Roussakis, "Crisis and Reform in Greek Education", European Education 35, no. 3, (2003): 7-30.

26 Additional view for a critique: N. Paleologou and O. Evangelou, Intercultural pedagogy. Educational,teaching and psychological approaches. (Athina: Atrapos, 2003); Faas,"Between ethnocentrism," 163-83; Kazamias and Roussakis, "Crisis and Reform," 7-30; Markou, "Intercultural Education," 32-43; Michael, Damanakis, $H$

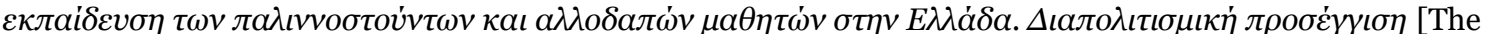
education of co-ethnic and foreign pupils in Greece. An intercultural approach](Athens: Gutenberg, 1997). ${ }_{27}$ Palaiologou and Faas, "How 'intercultural' is," 563-84; Faas, "The Nation," 471-92.
} 
lacks global perspective, leading students to stereotypes or misconceptions about world cultures.

\section{Methodology and terminology}

To discuss the findings and avoid any misperceptions around the terms intercultural and citizenship education the author uses the term intercultural education with reference to ethnic and cultural diversity. Overall, it is used to describe 'the approach whereby processes of interactions and understanding are promoted and ethical considerations are developed among people with cultural backgrounds' 28 . The term citizenship education is used with reference to the wider range of forms of plurality and diversity i.e. culture, language, religion, gender, socio-economic status, disability etc. 29 discussed by the specific (statutory) school subject of civic and citizenship. Looking into terminologies it is worth mentioning that the boundary between civic and citizenship education is not often perfectly clear. However, civic education has often a narrower scope than citizenship. Whereas, civic education or civics usually refers to the process of transmitting knowledge concerning a country's constitutional structure and political institutions, citizenship education covers additional competences such as social responsibility, as well as skills for ensuring effective interpersonal relations and successful personal development.30

Since the terms 'ethnocentrism' and 'eurocentrism' touch on a nation's sensitivities, to avoid any confusion and to address the Greek civic curriculum's character, the conceptual framework that was developed by Daniel Fass (2011a, 2011b) has been used for the purposes of this essay. Faas developed an analytical framework that linked European and multicultural educational dimensions while exploring the extent to which Europe and multiculturalism had been intertwined in geography, history and citizenship education curricula, on the basis of selected groups, grades and curricula across three European countries: Germany, England and Greece. By looking into the curriculum for students aged between $10-15$ who had been attending five years of compulsory schooling, Faas (2011a, 2011b) counted the number of units across the five age groups, and analysed the units' content (methodology of content analysis) when referred to Europe, multiculturalism and the nation, across the three abovementioned subject areas. In so doing, he provided unique insights and a reliable framework for examining the final two years of primary school curricula and of the junior high school ones. ${ }_{31}$ The curricula and textbooks examined were introduced gradually in 2006.

In this paper, we additionally discuss the content of the civic and citizenship textbook for High School Year 10 students (15 - 16 years old). This was accomplished with the use of simple technique based on principles adopted by the 'text mining' method,

28 J.S. Gundara, Interculturalism, Education and Inclusion. (London: Paul Chapman 200o); C. AllemannGhioda, "From Intercultural Education to the Inclusion of Diversity: Theories and Policies in Europe," in International Companion to Multicultural Education, ed. J.A. Banks, (London: Routledge, 2009), 135; A. Portera, "Intercultural and Multicultural Education: Epistemonological and Semantic Aspects," in Intercultural and Multicultural Education. Enhancing Global Interconnectness, ed. C.A. Grant and A. Portera (London: Routledge, 2011), 12-32.

${ }_{29}$ C. Allemann-Ghioda, Intercultural Education in Schools: A comparative study (Brussels: European Parliament, 2008); C. Allemann-Ghioda, "Intercultural Education in Europe: Epistemonological and Semantic Aspects," Intercultural Education 19, no. 6, (2008): 481-91.

3о European Commission/EACEA/Eyridice, 2017, Eurydice Report.

${ }_{31}$ Faas, "The Nation," 471-92; Faas "Between ethnocentrism," 163-83. 
employed for text documents.32 According to this simple technique, a list of concepts around Europe and non-European countries - generated from the textbook - were selected with the aim to identify the trends around eurocentrism only (see Figure 1). Then, a frequency table was developed in order to record the number of repetitions of the given terms in the document. The recording took place with the assistance of key term searches. Depending on the number of times the selected words appeared in the document, and the content that was attributed to them some general conclusions were drawn (see Table 2).

Turning to Faas's (2011) typology that was adopted across countries, subject curricula are clustered into four categories known as: national, multicultural, monocultural and European (see Figure 1).

Figure 1: Faas' Typology on Ethnocentrism and Eurocentrism

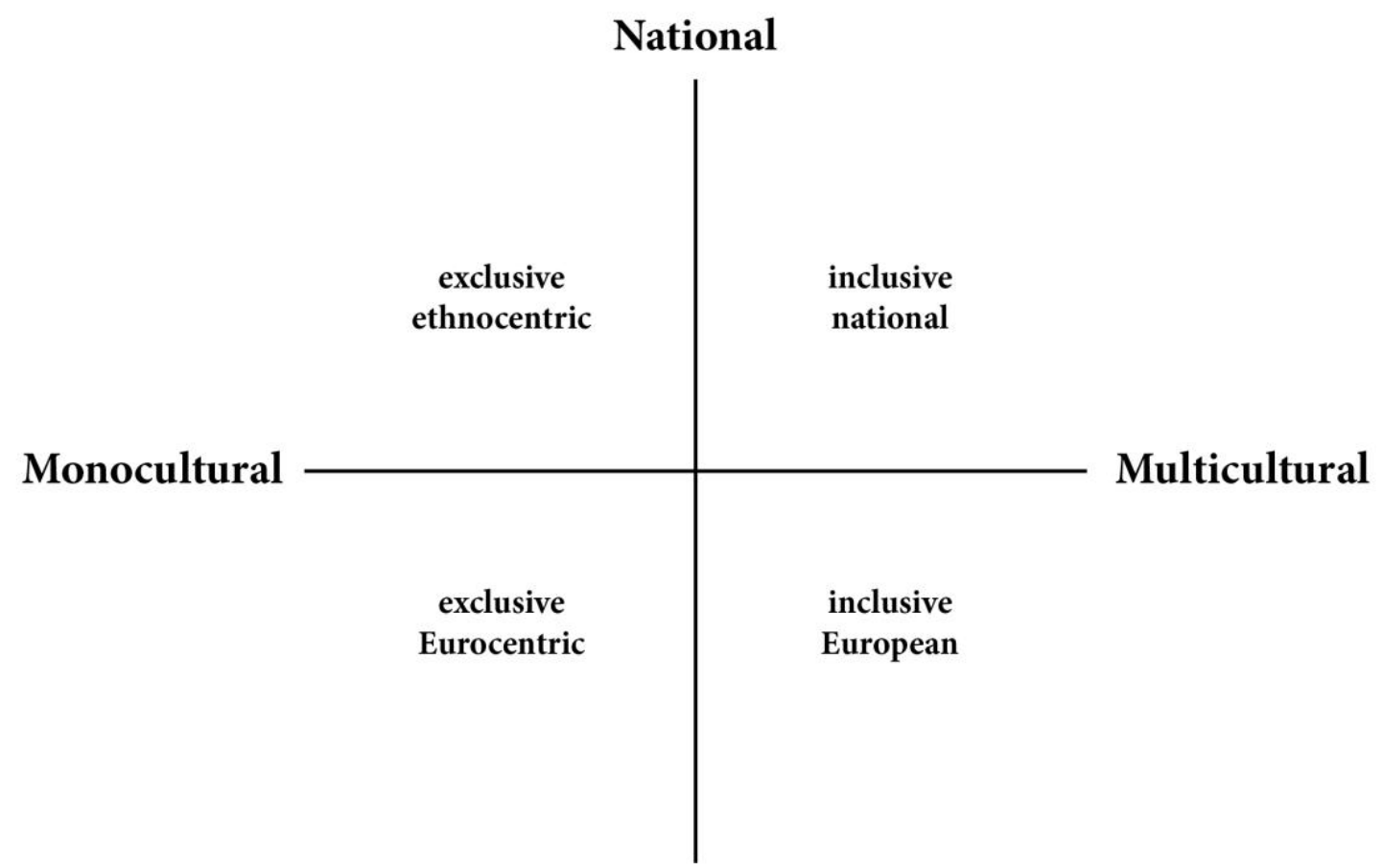

\section{European}

Source: Daniel Faas (2011): The Nation, Europe and Migration: A comparison of geography, history and citizenship education curricula in Greece, Germany and England, Journal of Curriculum Studies, 43:4, p.480.

The 'national' dimension can be referred to the national inclusive curricula (i.e. those including a range of multicultural topics combined with a national dimension). On the other end of the spectrum, there is a European dimension. This category may include curricula with a broad range of multicultural topics combined with a more European dimension; looking at the opposite axis, in the multicultural dimension, the "exclusive eurocentric curricula" that are underpinned by a strong European dimension and few, if any, units around ethno- cultural diversity can be found. The fourth and last category is referred to as the exclusive ethnocentric curricula. Those curricula usually 
demonstrate strongly the national dimension having limited units around ethnocultural diversity.33

\section{Citizenship education policy and practices in Greece 'between Ethnocentrism and Europeanism': Research findings}

Based on the above categories, Faas's (2011a, 2011b) content analysis of the Greek civic and citizenship curricula has indicated that the subject's textbooks place more emphasis on national topics in comparison to European and global ones.

This emphasis on national topics is stronger in the subject of history, but it also prevails in the subject of civics and geography. In discussing this asymmetry between the national and the European topics included in the country's civic curricula, one could argue that the subject's textbooks fused notions of ethnocentrism and Europeanisation. This was achieved by a focus on Greece's political system, the Greek state's structures, Greek citizens' rights and responsibilities, the Greek Constitution etc. and aspects of the EU's integration.34

Global and diversity issues were promoted less than national topics. When the civics textbooks showcased topics around Europe, those were defined mainly in political terms. Thus, Europe was identified as a synonym for the European Union. This 'special emphasis on Europe' coupled with units in which Europe appeared as synonymous with the EU (e.g. Greece and the European Union) amounted to a sense of Eurocentrism being added onto the prevailing ethnocentrism.35

When presenting European themes, the civic's textbooks referred concurrently to Greece. Research indicated that curricula drew many comparisons between Greece and Europe by constructing Europe as an 'add-on' dimension compatible with the Greek one.36 Studying the curriculum's content and focusing on the unit that describes and analyses the European Union, it appeared that the Greek citizen is often viewed also as a European one. Focusing on the Junior High School Year 9 civic curriculum it can be observed that in the unit entitled 'The Individual and the European Union' the Greek citizen is clearly constructed as a European one, demonstrating the MoE's subject's guidelines to raise students awareness around the fact that they are 'Greek and European citizens at the same time'.37

Having discussed Faas's (2011a, 2011b) conclusions on the Greek Civic and Citizenship's curriculum's 'veering between ethnocentrism and eurocentrism' it becomes obvious that the textbook is a 'long way from recasting the Greek nation in European terms' as it has been argued by scholars who study global tendencies. 38 The numerical supremacy of national topics over European ones indicates the Greek state's intention to foster strongly Greece's national identity (see Table 1).

\footnotetext{
${ }_{33}$ Faas, “The Nation," 471-92.

${ }_{34}$ Faas, "Between ethnocentrism," 163-83 and Faas, "The Nation," 471-92.

${ }_{35}$ Faas, "Between ethnocentrism," 163-83.

${ }_{36}$ Faas, "Between ethnocentrism," 163-83.

${ }_{37}$ Official Government Gazette, 2003.

38 H. Schissler and Y.N. Soysal, eds, The Nation, Europe and the World: Textbooks and Curricula in Transition

(Oxford: Berghahn Books, 2005).
} 
Table 1: National, European and multicultural issues - Greek civic and citizenship curricula in Greece (Junior High School Year 9 students (14 - 15 years old)

\begin{tabular}{|c|c|c|c|}
\hline TOPICS & National topics & European topics & Multicultural topics \\
\hline Citizenship & 46.2 & 23.1 & 23.1 \\
\hline
\end{tabular}

Source: Daniel Faas (2011): The Nation, Europe and Migration: A comparison of geography, history and citizenship education curricula in Greece, Germany and England, Journal of Curriculum Studies, 43:4, p.480.

Focusing on the topics of cultural diversity, research indicated that although the civic and citizenship curriculum included sub-units on cultural diversity issues, these referred to global and international community themes such as global transportation networks, instead of multicultural topics such as migration.39 Research also indicated that countries and cultures beyond Europe or outside the EU remained largely unexplored.

Evidence from the Greek civic and citizenship curricula in Greece aiming at High School Year 10 students (15 - 16 years old), gathered on the basis of the author's observations while teaching the subject, verify Faas' findings. In so doing, they signify the consistency of the subject's aims across all three stages of education. If one reviews the 190 pages of the textbook, one will find more references to the Greek state's institutions (religion, family, economy etc.). Having said that, the textbook contains a unit on immigration and two sub-units on the EU. The unit on immigration cites the phenomenon's religious and cultural diversity, but also contains many topics on the Greek diaspora, Greek repatriates and Greek citizenship acquisition. The unit on the EU comprises much information on the commonalities between the EU and Greece (i.e. Ancient Greek philosophy and culture) further confirming Faas' findings.

Investigating the Year 10 civic and citizenship curriculum topics on countries and cultures beyond Europe or outside the EU, one will find that these are largely marginalised. It is indicative that the word Europe and European Union appears 83 times in total, whereas the word Australia appears only 7, America 13 and Russia 4 times. The references to Australia are made exclusively in relation to the Greek diaspora and not the country's value system and culture (see Table 2).

Table 2: National, European and multicultural issues - Greek civic and citizenship curricula in Greece (High School Year 10 students (15 - 16 years old)

\begin{tabular}{|c|c|c|}
\hline Word & Times & Content \\
\hline Australia & 7 & Greek Diaspora \\
\hline \multirow[t]{4}{*}{ America } & \multirow{4}{*}{13} & North America (2) \\
\hline & & 'Developing'\& Developed countries (2) \\
\hline & & Industrialization (1) \\
\hline & & Diaspora (6) \\
\hline \multirow[t]{4}{*}{ Russia } & \multirow[t]{4}{*}{4} & Chernobyl (1) \\
\hline & & Greek diaspora (1) \\
\hline & & Country's value system (1) \\
\hline & & Greek Revolution of Independence (1) \\
\hline \multirow[t]{4}{*}{ Africa } & \multirow[t]{4}{*}{13} & Tsunami event (1) \\
\hline & & Development discourse (2) \\
\hline & & Continent's values (3) \\
\hline & & Immigration (2) \\
\hline
\end{tabular}

${ }_{39}$ Faas, “Between ethnocentrism,” 163-83. 
Source: The author (2020)

\section{Citizenship education curriculum's ethnocentric character: reasons}

In tracing the factors behind the civic curriculum's ethnocentric character in Greece, it is clear that these unsurprisingly lie in the construction of the state's national identity. Evidence indicates that there is an overall difficulty in combining national with intercultural values across various school subjects.40

Literature indicates that the country's constant projection of Hellenism's continuity from antiquity to today, and its association with 'Greekness', have been encouraging ethnocentric and monolithic approaches to identity.41 These approaches, still relevant to this day, have been introduced into the country's curriculum and teaching methods.

Exploring the country's national identity and its historic formation one can understand the challenges the country's attachment to the Hellenic roots poses towards facilitationg European integration. Researching the country's contemporary history, one can view the Greek state's and the Eastern Orthodox Church of Christ's role in shaping Greek identity with both classical memories and Byzantine traditions. 42 Since Greece's Independence from the Ottoman Empire in 1830, the Greek state and the Orthodox Church have been imposing their sovereignty with the formation of an ethnically and Orthodox identity based on 'Ethos', 'Ancient Greece' and 'Orthodox religion'. Although Greek nationalism in the 18th century was underpinned by Enlightenment ideals, the country's first decades of independence indicated the Greek nation state's need to adopt an ethno-cultural identity based on common ancestry, culture and 'Hellenic-Christian' religion.43

These elements, important for strengthening the nation-state against the perceived 'others', have led to a view of the Islamic identity as the 'Other', as different to Greekness. For this reason, this social group has been excluded from the 'nation-state's building process.44 Muslims are not the only ones excluded. The 'Greekness' narrative based on a triple self-definition has provided a triple boundary by distinguishing Greeks from Jews in the East but also Slavs in the north. 45

Exploring the idea of Greekness and its impact further, scholars argue that the notion has been determining the country's intercultural education for many years often by inhibiting its potential. It is not by chance that Greece's Intercultural Education policy

\footnotetext{
40 Triandafyllidou and Gropas, "Greek Education Policy".

${ }_{41}$ E. Avdela, "The teaching of history in Greece." Journal of Modern Greek Studies 18, no. 2, (2000): 239-53.

42 It is indicative that Article 3 of the Greek Constitution refers that 'the prevailing religion in Greece is that Eastern Orthodox Church of Christ' and Article 16 mentions that 'education shall aim at ....the development of national and religious consciousness and at the formation as free and responsible citizens' Additional view Official Government Gazette, 2001 in Faas, "Between ethnocentrism," 163-83.

${ }_{43}$ Paschalis Kitromilides, "Imagined Communities' and the Origins of the National Question in the Balkans," in Modern Greece: Nationalism and Nationality, eds. Blinkhorn M. and T. Veremis (Athens: ELIAMEP, 1990), 25-

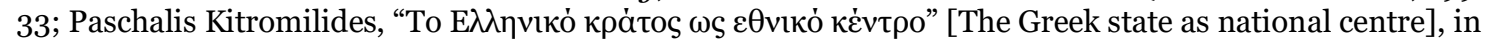

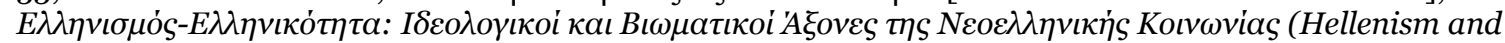
Greekness: Ideological and Biographical Axes of Modern Greek Society), ed. D. Tsaoussis (Athens: Estia, 1983). ${ }_{44}$ Palaiologou and Faas, "How 'intercultural' is," 563-84. 45 Triandafyllidou and Gropas, "Greek Education Policy”.
} 
was introduced in 1996, although the country had been receiving expatriates since the 1960s.

\section{Citizenship education curriculum's eurocentric character: reasons}

\section{a) MoE's eurocentric reforms in 2003}

In addressing the eurocentric character of the Citizenship curriculum many reasons require discussion. To begin with, one could refer to the MoE's reforms in 2003 and General Principle Four: 'Strengthening cultural and linguistic identity in a multicultural society'. Looking at this Principle and the subject guidelines it can be argued that the need to raise students' awareness of the fact that they are 'Greek and European citizens at the same time' had been explicitly stated by the Greek state in many key statements (see Table 3).

Table 3: General Principle's key statements about the EU 'Strengthening cultural and linguistic identity in a multicultural society'

\begin{tabular}{|l|l|}
\hline \multicolumn{2}{|l|}{ Key statements (principia) } \\
\hline 1 & $\begin{array}{l}\text { Mutual understanding and cooperation with other European peoples, so as to promote } \\
\text { development in all sectors }\end{array}$ \\
\hline 2 & $\begin{array}{l}\text { Enrichment of Greek society and other European societies with individual and groups that are } \\
\text { bearers of other cultures, so as to broaden cultural diversity }\end{array}$ \\
\hline 3 & $\begin{array}{l}\text { Respect for and acceptance of cultural difference among others, and harmonious coexistence } \\
\text { in multicultural environments }\end{array}$ \\
\hline 4 & $\begin{array}{l}\text { Development of social and communicative skills necessary for participation in contemporary } \\
\text { social developments }\end{array}$ \\
\hline 5 & $\begin{array}{l}\text { Cultivation of national and cultural identity in the spirit of cultural and linguistic diversity } \\
\text { provided for an article 126 of the Maastricht Treaty }\end{array}$ \\
\hline
\end{tabular}

Source: Official Government Gazette vol. ii 303/13-303 pp. 3735

The MoE's explicit strong emphasis on the EU, as highlighted in General Principle's Four statements, was not random. It was made in reflection and alignment with the Greek state's educational reforms that had been initiated a few years earlier known as EREFOM 2000. According to literature, in 2000 the MoE promoted one of the most important reforms of the century with the aim to address the Greek education system pathologies and modernise its character in a way that was relevant to 'the new European and global cosmos that was being constructed and in which Greece chose to place itself. 46 It was the era of the Lisbon Strategy (2000 - 2010) during which the EU strived to become a knowledge-based economy and member states attempted to modernise their curriculum content while restructuring education.

\section{b) National identity as the cradle of the EU's civilization}

Apart from the Greek state's effort to adjust to the architecture of neo-European modernity, one could also support the idea that the country's endeavours to 'construct' the national identity around the idea of 'Greekness' has also played a role towards the civic curriculum's eurocentrism.

Regardless of the statement's oxymoron, theorists support that the construction around Greekness has led 'a small and economically underdeveloped country in the 
southeastern periphery of the European continent into a central symbol of the construction of a European civilization' ${ }_{47}$ It has enabled the Greek civilization to be considered as the cradle of the European one by nurturing associations around Greece's and Europe's common identity. Over the years, successive Greek governments have stressed the cultural relationship between Greece and Europe, underpinning the Greek claim that they are European, and that Europeans are Greek since they share the values of democracy, equity and justice. In so doing they have managed to ingrain this conceptualisation into the collective consciousness.

\section{c) The policy makers' role in promoting the EU idea}

The efforts of successive national governments and bureaucrats to promote Europe's role, due to the country's membership into the EU, may be considered as another reason for the civic and citizenship curriculum's eurocentric character. Ever since the country joined the European Union most administrations have been supportive of its education undertakings. Qualitative research on education policy makers', bureaucrats' and high-level civil servants' attitudes and perceptions around Europe demonstrated this affiliation.48 This highlights the dichotomy that often exists between EU and non-EU citizens (known as Third Country Nationals) in peoples' minds. 49 It is indicative that one of the participants argued 'Greeks are not threatened by the notion of Europe or being European citizens, however we feel that some 'others' do not share the common European values such as human rights and democracy.'5o

Interview rounds with Curriculum Advisors at the Ministry of Education indicated the lack of contradiction between European and Greek values, since policy makers did not perceive Europe as the 'other'. In fact, they implied that Europe and the European identity were conceived more as a fait accompli rather than a cultural challenge. 51 Therefore, most policy makers agreed that educating Greek students to behave as Greek and European citizens did not pose a cultural challenge, since Greece was part of Europe. They felt that 'speaking about Europe is like speaking about themselves'.52 In discussing the civic curriculums' content most of the interviewees supported that '....the textbooks of the last decade stressed a European dimension more than the textbooks before that'.53

The dichotomy between EU and non-EU citizens was evident when policy makers were asked about the intercultural education role. According to them, intercultural education was about the successful integration into the school system of children whose parents are economic immigrants or co-ethnic returnees from Soviet Republics or Albania and non-European citizens.54

\footnotetext{
${ }_{47}$ Constantine Tsoukalas, "Greek National identity in an integrated Europe and a Changing World Order," in Greece, the New Europe and the Changing International Order, eds. H. Psomiades and S.Thomadakis (New York: Pella).

48 More information on the research's methodology see: Gropas and Triandafyllidou, "Greek education policy," 399-419; Triandafyllidou and Gropas, "Greek Education Policy".

49 The fact that European citizens can only be those who are already citizens of national member state (Maastricht Treaty, Article 8) often leads to this dipolar opposition of "We Europeans" and the Others often, Additional view: Damanakis, "European and Intercultural Dimension," 79-88.

5o Faas "The Nation," 471-92; Faas, "Between ethnocentrism," 163-83.

${ }_{51}$ Triandafyllidou and Gropas, "Greek Education Policy".

${ }_{52}$ Triandafyllidou and Gropas, "Greek Education Policy".

${ }_{53}$ Faas, "The Nation," 471-92; Faas, "Between ethnocentrism," 163-83.

54 Triandafyllidou and Gropas, "Greek Education Policy".
} 


\section{d) The EU's role towards transforming member states' civic curricula and policies}

In exploring the ways in which the Greek state's national identity formation and government officials' attitudes have impacted the specific school subject in Lower and Upper Secondary School, one cannot neglect but to view the Greek state's response to the EU's intercultural and citizenship policy calls.

Broadly, the EU's role and impact on the civic and citizenship curriculum's character in Greece forms part of the wider discussion that has been taking place around the EU's ability to transform countries' national curricula by promoting common intercultural and civic education policies. The challenges of the 1950s migration flows have propelled the EU towards delivering policies and practices in the field of intercultural and citizenship education. Beginning in the late $1^{1960 S_{55}}$ and continuing in the $19705_{56}$ the EU has introduced and implemented intercultural policies in field of education. These policies have raised concerns related to the EU's role, authority, soft law mechanisms and outcomes. To address the EU's input to the Greek civic curriculum's eurocentric character it is important to address the EU's relationship with Greece while reflecting also on the wider discussion.

Looking into the EU's role, it remains a fact that, via the Principle of Subsidiarity and soft law approaches such as the Open Method of Coordination (OMC), it promoted initiatives that addressed the issues of intercultural learning, ethno- cultural education and religious diversity (1980s) citizenship education (1990s) and University students' intercultural learning (Erasmus Programs). After the Maastricht Treaty (1992), when the EU's role in education was strengthened by Article 126 provisions (Chapter 3), the EU launched even more programs (i.e. Socrates), recommendations and initiatives for member states.57

Observing the European integration process, scholars have supported the idea that over the years the EU has become a major supranational player in the area of education. 58 By raising the profile of school-related issues on the EU agenda and promoting many shared intercultural policies among member states, these theorists have argued that the EU has developed a common intercultural education policy. These common principles, that focus on 'equal education opportunities to culturally and ethnically diverse groupings, regardless of their origin, social rank, gender and disability', 59 have transformed national, ethnocentric educational systems and curricula into more inclusive ones.6o

\footnotetext{
${ }_{55}$ Council of the European Community (1968), the Council Resolution on the Freedom of movement for workers within the Community (No 1612/68). Brussels: EC.

${ }_{56}$ Council of the European Community (1977) the Council Directive of 25 July 1977 on the Education of the Children of Migrant workers (77/486/CEE). Brussels: EC.

${ }_{57}$ The acronym ERASMUS is read as European Community Action Scheme for the Mobility of University Students.

${ }_{58}$ For example: Council of Ministers of Education, "Resolution of the Council and the Ministers of Education: Meeting within the Council on the European dimension in education of 24 May 1988," Official Journal of the European Communities C 177: 5-7.

59 James Banks and Cheryl \& McGee Banks, eds, Multicultural education. Issues and perspectives, 7 th ed. (Hoboken, NJ: John Wiley \& Sons Publishers, 2009); A. Portera, "Intercultural education in Europe: Epistemonological and Semantic Aspects," Intercultural Education 19, no. 6, (2008): 481-91.

6o H. Schissler and Y.N. Soysal, eds., The Nation, Europe and the World: Textbooks and Curricula in Transition. (Oxford: Berghahn Books, 2005); Portera, "Intercultural education in Europe," 481-91; S. Philippou, "Re-
} 
In discussing members state response to the EU's calls many scholars have argued that despite the EU's unifying efforts for a common intercultural education policy in the wake of increasing migration and diversity, member states have always retained their autonomy in the field. Thus, they have implemented EU practices under assimilationist frameworks and through their national, ethnocentric curricula. This latter argument appears to be a rather strong one, since EU actions serve mainly to complement and support national level initiatives. According to the EU's institutional arrangements, the organisation has no power to pass laws in this field. In other words, the EU cannot interfere in member states' ability to legislate. Thus, it can only support, coordinate or complement the action of member states.61 Therefore, the EU has supported members states usingtheir powers to safeguard nationalist and ethnocentrism discourses.62 It has been argued that the EU's structural barriers and OMC's limitations have inhibited the EU's ability to transcend national curricula and national trajectories of migration. Historically, European countries with relatively high immigrant flows (such as France, Germany, the United Kingdom, Belgium and the Netherlands) have introduced their own measures to confront challenges in the area of intercultural policy. After, 'pedagogy for foreigners' in Germany, or 'pedagogy of assimilation' in France between the 1950s -1970s, countries diversified their intercultural policies significantly depending on their citizenship acquisition requirements and migrant flows. When citizenship education was introduced in the 1990s, member states responded again with variations related to subject content, instruction time, assessment, teachers' qualification and ways in which the citizenship education is integrated into national curricula.

Greece, has been influenced by the EU's intercultural and citizenship policy due to the country's distinct relationship with the EU in the area of education. Literature indicates that while Greece joined the European Economic Community/European Union in 1981, it soon after began to support the development of a joint education policy. This attitude was expressed on the belief that the country's accession 'had formalized its belonging and confined that western Europe has been the main political and cultural reference since the creation of the modern Greek state in the early 19th century'.63

Researching the country's relationship with the EU, one can observe the EU's influences in the country's policies and trace the milestone events that led to its eurocentric curriculum after 2000 and onwards. Although it seems there is only limited awareness of the ways in which the EU's Resolutions and Directives have affected the character of the Greek civic and citizenship curriculum,64 observing the country's policies in the area of intercultural education indicate the country's positive response to the EU's calls for a common policy in this area after the mid-1990s.

inventing Europe: the case of European dimension in Greek Cypriot geography and history curricula," The Curriculum Journal 18, no. 1, (2007): 57-88.

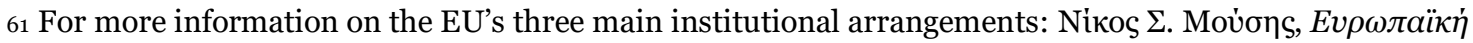

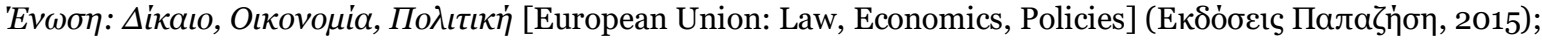

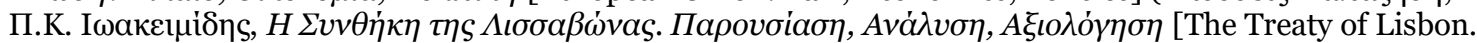

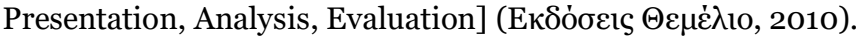

${ }_{62}$ P. Hansen, "Schooling a European identity: Ethnocultural exclusion and nationalist resonance within the EU policy of the European dimension of education," European Journal of Intercultural Studies 9, no.1, (1998): 5-23. ${ }_{63}$ Anna Triandafyllidou and Ruby Gropas, "Cultural Diversity in Greek Public and Political Discourses.A European Approach to Multicultural Citizenship: Legal Political and Educational Challenges, EMILIE,” (2007). ${ }_{64}$ Triandafyllidou and Gropas, "Cultural Diversity in Greek Public and Political Discourses". 
Prior to this milestone, the country had been following its own assimilative and ethnocentric approach. Even though bound by EU Directive 77/486/EEC,65 Greece did not consider teaching foreign pupils' mother tongue or culture of origin a priority for a long time, since learning Greek was considered as a vehicle for integration. In the case of Law 2413/1996, although its provisions had been in line with the contemporary European modernisation discourse, the country's ethnocentric approach had impacted the legislation's 'intercultural' character and consequently it had raised concerns.66

Research shows that the concerns related to Law 2413/1996, expressed at a national but also at a European level, had resulted also from the country's various stakeholders' participation in EU funded initiatives and programs aimed at the promotion of intercultural education. These initiatives created the opportunity for discussions and problematisation around the country's intercultural policy, by also encouraging more pro-European feelings around the EU's intercultural policy. Research indicates that these initiatives led to the country's pro - European curriculum changes in 2003.67

Until the 1990s the EU and core political and economic issues of European integration had been absent from the country's school curricula and textbooks. In spite of this absence, there is evidence that the country's youth had formed attitudes, expectations around the EU and its mission early on.68 It could be argued, then, that the formation of these attitudes and expectatios is the outcome of the EU's soft and hard law policies in the area of intercultural education policies. Studies have indicated that the country's intercultural and citizenship policy has been impacted by the Council of Education Ministers' Resolution, introduced in 1988 with the aim to 'strengthen in young people a sense of European identity'.69 Research has also indicated that the country's educational system has been influenced by the Council of Education Ministers' Green Paper on the European dimension of education that was launched five years after the Resolution $_{70}$ and the White paper on Education and Training (1995). ${ }_{71}$ The Green Paper, that suggested ways of cooperation among students, parents, teachers' administrators and trainers, encouraged the country's participation in various training and exchange programs delivered for students and teachers (via SOCRATES, LEONARDO, LINGUA, COMENIUS, ARION etc.). It thus brought the country closer to Europe and shifted its strong ethnocentric focus towards a more eurocentric one (see Table 4).

Focusing on the aforementioned exchange programs' rationale it is important to stress that these were initiated to connect member states school communities and foster collaborations across universities, in order to discuss and promote the EU's agenda on intercultural education policy. In so doing, these programs fostered best practice

\footnotetext{
${ }_{65}$ Council of the European Community (1977) the Council Directive of 25 July 1977 on the Education of the Children of Migrant workers (77/486/CEE). Brussels: EC.

66 Kazamias and Roussakis, "Crisis and Reform in Greek Education", 7-30.

${ }_{67}$ Damanakis, "European and Intercultural Dimension," 79-88.

68 Georgia Kontogiannopoulou-Polydorides, Mary Kottoula and Kelly Dimopoulou, "Citizen Education: Silencing Crucial issues,” Journal of Modern Greek Studies 18, 287-303.

${ }_{69}$ Council of Ministers of Education, "Resolution of the Council and the Ministers of Education: Meeting within the Council on the European dimension in education of 24 May 1988," Official Journal of the European Communities C 177: 5-7.

7o Council of Ministers of Education. Green Paper on the European Dimension of Education. Luxembourg: Office for Official Publications on the European Communities, 1993.

${ }_{71}$ European Commission. The White Paper on education and Training. Teaching and Learning: Towards the Learning Society. Luxembourg: Office for Official Publications of the European Communities, COM (95) 590 final 1995 .
} 
exchange, benchmarking among states and more openness towards the EU's calls on intercultural and civic education. From the literature on the topic, it is known that Greece strongly supported these initiatives. Statistics indicate that from the commencement ofg the European exchange programs, Greece's primary and secondary schools' participation was very high satisfactory.72 Participation by Greek universities, student and staff mobility was also considerable, 73 resulting in more proEuropean sentiments and attitudes.

At a national level, these exchange programs promoted numerous mutual interchanges among members states and EU policy makers. Via the OMC, these exchange programs encouraged the diffusion of ideas and policies and provided opportunities for forums, roundtables, conferences, transnational European meetings among stakeholders. In practice, it is known that these programs offered national stakeholders opportunities for reflection around their country's educational system ability to compete in an increasingly globalized and competitive environment; and integrate successfully into the European Union.74 In the case of Greece, these reflections provided the foundation for the country's curriculum reforms in 2003, since Greece's intercultural policies were questioned by its European partners. 75

In reviewing the EU's impact on Greece's intercultural and civic education, one could also argue that the launch of three large scale educational programs co-funded by the EU, between 1997 - 200476 also impacted the country's policies in the relevant field. These programs, aimed at providing the Muslim minority, Roma, foreign and expartiate pupils with the opportunity to 'enjoy to the outmost the education system's benefits so that they later on participate actively in society, while at the same time maintain their own cultural identity', 77 promoted academic dialogue around intercultural issues and better school practices. 78

To understand contemporary curricular developments in the subject of civics and citizenship in Greece and discuss its ethnocentric and eurocentric character, the author referred inevitably to the country's 'construction' of national identity and reviewed the country's relationship with the EU in the field of intercultural and citizenship policy. By discussing the most important milestone events, the author presented the EU's influence on the country's intercultural policies and explained its shift towards a more eurocentric position expressed in its civic and citizenship curriculum.

\footnotetext{
72 Dimitris Mattheou, "National Report on the Implementation for the Socrates Programme in Greece, 200o2003: Laboratory for Comparative Education, International Educational Policy and Communication, (National and Kapodistrian University of Athens, 2003).

${ }_{73}$ Andreas Moschonas, Education and Training in the European Union (Aldershot: Ashgate, 1998).

${ }_{74}$ Faas, "The Nation," 471-92. Faas, "Between ethnocentrism," 163-83.

75 Damanakis, "European and Intercultural Dimension," 79-88.

76 In 2003 the Greek Ministry of Education initiated the second phase of these three large EU funded Programmes' implementation. Some years later, in 2010, the EU supported the Greek Ministry of Education towards assigning to Universities the delivery of new intercultural resources targeted to address the needs of the socially excluded students. Additional view: Triandafyllidou and Gropas, "Greek Education Policy and the Challenges of Migration".

${ }_{77}$ Paleologou and Evangelou,"Intercultural pedagogy"; Triandafyllidou and Gropas, "Greek Education Policy and the Challenges of Migration".

78 Damanakis, "European and Intercultural Dimension," 79-88.
} 
Table 4: EU's and Greece's policy initiatives in the area of intercultural policy (1983-2003)

\begin{tabular}{|c|c|c|}
\hline Period & European policies & National policies \\
\hline 1977 & $\begin{array}{l}\text { EEC Council Directive in } 77 / 486 / E E C \\
\text { incorporated into Greek law }\end{array}$ & \\
\hline $1982-1984$ & & $\begin{array}{l}\text { Repatriated students' school } \\
\text { integration "Deficit period" }\end{array}$ \\
\hline 1983 & & $\begin{array}{l}\text { Law 1404/83 setting up } \\
\text { Reception Classes and Tutorial } \\
\text { Courses for return and foreign } \\
\text { pupils }\end{array}$ \\
\hline 1986 & Single European Act & \\
\hline 1988 & $\begin{array}{l}\text { Resolution of } 24 \text { May } 1988 \text { on the European } \\
\text { dimension in education }\end{array}$ & \\
\hline 1990 & & $\begin{array}{l}\text { Amendments } \\
\text { improvements to Law 1404/83, } \\
\text { so as to render Reception } \\
\text { Classes and Tutorial Classes } \\
\text { more flexible and productive }\end{array}$ \\
\hline 1992 & Maastricht Treaty & \\
\hline 1993 & $\begin{array}{l}\text { Green Paper on the European dimension in } \\
\text { education }\end{array}$ & Country's participation \\
\hline $1994 / 99$ & Commencement of Socrates Program & exchange programs \\
\hline 1995 & White Paper on education and training & \\
\hline 1996 & & $\begin{array}{l}\text { Law } 2413 / 1996 \text { on intercultural } \\
\text { education in Greece }\end{array}$ \\
\hline 1997 & & $\begin{array}{l}\text { Enactment of Law } 2525 / 1997 \\
\text { On Greek education abroad and } \\
\text { on intercultural education }\end{array}$ \\
\hline & $\begin{array}{l}\text { 1997- } 2001 \\
\text { EU funded initiatives } \\
\text { European Union supported First Operational } \\
\text { Plan for Education and Initial Vocational } \\
\text { Training (EPEAEK 1) } \\
\text { Education for Roma children } \\
\text { Education for Muslim children } \\
\text { Education for return and foreign pupils } \\
\text { Participation in Socrates, Leonardo Da Vinci, } \\
\text { Youth for Europe and other European } \\
\text { programs }\end{array}$ & $\begin{array}{l}\text { Country's participation in EU } \\
\text { funded programs for } \\
\text { marginalised groups and } \\
\text { intercultural education }\end{array}$ \\
\hline 2000 & Lisbon Treaty & \\
\hline 2001 & Continuation of (a), (b), (c) Programs & $\begin{array}{lrr}\text { Country's participation in } & \text { EU } \\
\text { funded } & \text { programs } & \text { for } \\
\text { marginalised } & \text { groups } & \text { and } \\
\text { intercultural education } & \text { until } \\
2010 & & \\
\end{array}$ \\
\hline 2003 & \multicolumn{2}{|c|}{$\begin{array}{l}\text { Incorporation of the European and intercultural dimension into the official new } \\
\text { curriculum for compulsory nine - year education, following the general principle } \\
\text { of 'strengthening of cultural and linguistic identity within a multicultural society' }\end{array}$} \\
\hline
\end{tabular}

Source: The author, 2020

\section{Finding intercultural solutions - 'Melbourne - Athens: A Journey of Friendship' program}

Today, it appears that one of the major challenges for European education systems is to overcome the persistent eurocentric elements by engaging students effectively and 
providing all pupils with the required skills for full active citizenship both in Europe as well as in the rest of world.79 In the case of Greece, the challenge is to overcome this 'veering between ethnocentrism and eurocentrism that marginalises topics of immigration and diversity'. 8o Otherwise students will not succeed in developing culturally, in increasing their awareness around the nature and role of various groups, and readiness to accept diversity'. 81 Students will fail to adhere to the EU's recommendations to 'take responsibility for themselves and for their communities at the local, regional, national and international level' 82 if the curricula lack themes associated with countries and cultures beyond Europe or outside the EU.

Content knowledge, including teaching and learning topics included in the teaching program is an absolute priority towards addressing the challenges that arise from ethnocentrism's and eurocentrism's stereotypes. However, educators should also be encouraged to design and deliver more practical experiences for students. Experiences that prepare students for their role as citizens in the 21st century and engage them more actively and interculturally. 83

It is for this reason, that the author of this article, designed and delivered as a pilot, pro bono, the educational 'Melbourne- Athens: a Journey of Friendship' program for two years. During its pilot phase, the program was offered as an extra-curricular activity to three schools located in two countries. These schools - that had not collaborated in the past - were:

- The Greek Community of Melbourne's Language and Culture Schools (Bawlyn Campus \& Doncaster), 84

- Alphington Grammar (Melbourne, Australia) 85 \&

- The Hellenic American Education Foundation (Athens College - Psychico College).86

Each school had different characteristics. The Greek Community of Melbourne's Language and Culture Schools - one of the oldest Greek diaspora's institutions to offer Greek learning lessons and courses in the State of Victoria - offers Greek language and culture lessons for three hours per week, out-of-school hours (and on Saturdays) on 10 campuses located across Melbourne. Alphington Grammar school is a mainstream school. While it is organically connected to the Greek Community of Melbourne's Language and Culture Schools, it is a Bilingual Independent school that operates daily. The same applies to the Hellenic American Educational Foundation (Athens College Psychico College/HAEF), which is one of Greece's oldest Independent schools. Located in Athens, HAEF is a mainstream school that operates daily offering the Greek curriculum. Although independent it is supervised by the Greek Ministry of Education.

All three schools collaborated to implement the 'Melbourne - Athens' Program which at its core was established on the technology, one-on-one peer mentoring, and distance learning triptych for acquiring the Greek language. It aimed at linking Year 10 students

${ }_{79}$ Catarci, "Intercultural education," 98.

8о Faas, "The Nation," 471-92; Faas "Between ethnocentrism," 163-83.

${ }_{81}$ Official Government Gazette, 2003; Daniel Faas, "Between ethnocentrism and Europeanism? An exploration of the effects of migration and European integration on curricula and policies," Ethnicities 11, no. 2, (2011): $163-183$. 82 European Commission/EACEA/Eyridice, 2017, Eurydice Report.

$8_{3}$ European Commission/EACEA/Eyridice, 2017, Eurydice Report.

84 More information: https://www.facebook.com/gcmschool/ .

85 More information: https://www.alphington.vic.edu.au/ .

86 More information: https://www.haef.gr/en. 
who grew up and lived in Greece with Year 9 Greek-Australian students, born and raised in Melbourne, in order to improve their oral communication and capacity in the Greek language. ${ }_{77}$ It also aimed at fostering students' intercultural awareness skills since the students shared Greek heritage but had grown up in different societies. Towards achieving the program's aims, students learnt to respond to specific roles. During its pilot phase the students raised in Greece played the Program's mentors since Greek is their mother tongue - while the Greek Australian students were the program's mentees.

Designing the program's intercultural learning activities was one of its main challenges. As indicated, countries and cultures beyond Europe or the EU remain largely unexplored by the subject of civic and citizenship. In school- based programs, mentoring relationships rely upon trust, mutual respect and empathy that is created when students share common experiences in the same physical space. This essential prerequisite for the online mentoring program was addressed through the delivery of intercultural learning material (Learning Diaries) that covered topics that interested youth such as: traveling, hobbies and interests, etc., as well as topics on both countries' cultures and civilisations. In parallel, it was achieved via the initiation of: formalised 'Train the Mentors' activities,88 delivery of an intercultural tool kit that consisted of videos, attitude and perception quizzes, school visits to the Australian Embassy in Greece and library-based projects on Australia, multiculturalism, and immigration. Intercultural learning was also achieved via preparing mentees to act as 'Australia's Ambassadors' and combat mentors' stereotypes. Taking into consideration that 'youth who feel that their mentor takes their preferences and interests into account are more likely to show improvement and participation than youth who feel their mentor is less interested in them,' 89 and that 'the extent to which mentors and youth share interests determines the relationship's quality' 9o the 'Melbourne - Athens' Program also delivered a culturally sensitive matching tool (questionnaire) to 'match' mentors and mentees according to their interests.

Prior to the one-on-one mentoring meetings, the program executed a 'Group Skype Session' (Kick-off meeting) to familiarise students culturally with each other's environment (i.e. the seasonal and time difference). The program also promoted many activities that prompted students to go beyond the set textbooks and enrich the online mentoring relationship. These activities were offered in collaboration with community organisations, museums i.e. Immigration Museum, Museums Victoria in Melbourne, and the Ithacan Philanthropic Society. In parallel, intercultural object learning was encouraged via the delivery of two parcels with traditional Australian artefacts, maps,

${ }_{87}$ Greek language learning and effective pedagogical interventions remain a very complex issue. To efficiently support an educational initiative, one must have knowledge around the Greek language learning environment and address the individual factors that affect Greek language learning - i.e. students' and parents' attitudes towards Greek language learning, as well as the language policy of both the Victorian and Greek state. See for examples: G. Bottomley, "Multiculturalism in practice: A study of Greek Australian families in Sydney," in Greeks in Australia, eds. Karardis G. and A.M. Tamis (Melbourne: River Seine Press, 1988); J.J. Smolicz, "Tradition, Core Values and Cultural change among Greek Australians," in Greeks in Australia, eds. by Karardis G. and A.M. Tamis (Melbourne: River Seine Press, 1988).

88 See for example: P. Willis, R. Bland, L. Manka and C. Craft, "The ABC of peer mentoring - what secondary students have to say about cross-age peer mentoring in a regional Australian school.” Educational Research and Evaluation 18, no. 2, (2012): 173-185.

89 Jean Baldwin Grossman, and Jean Rhodes, "The test of time: predictors and effects of duration in youth mentoring programs." American Journal of Community Psychology 30, (2002): 199-206. ${ }_{90}$ Carla Herrera, Amy J. A. Arbreton, Cynthia L. Sipe, Sarah K. Pepper and Wendy S. McClanahan, Mentoring School-Age Children: Relationship Development in Community based and School based Programs (Philadelphia: Public/Private Ventures, 2000). 
post cards; resources about the Greek diaspora's contribution in Australia, and Australian wildlife were sent to the school in Athens. All initiatives required teachers' participation and the Coordinator's continuous brokering between the program's schools, located in the two countries.

During the program's two-year implementation (2016 - 2017) 66 students participated and up to 462 online peer mentoring sessions took place, providing new insights to educators in order to implement less ethnocentric and more inclusive curriculums and programs. In 2017 the 'Melbourne - Athens: A Journey of Friendship' was nominated for Victoria's Multicultural Awards for Excellence.

\section{Bibliography}

Allemann-Ghioda, C. "Intercultural Education in Europe: Epistemonological and Semantic Aspects.” Intercultural Education 19, no. 6, (2008): 481-91.

-Intercultural Education in Schools: A comparative study. Brussels: European Parliament, 2008.

_-From Intercultural Education to the Inclusion of Diversity: Theories and Policies in Europe." In the International Companion to Multicultural Education edited by Banks, J.A: 134-145. London: Routledge, 2009.

Avdela, E. “The teaching of history in Greece.” Journal of Modern Greek Studies 18, no. 2, (2000): 239-253.

Banks, James and Cheryl \& McGee Banks, eds. Multicultural education. Issues and perspectives. 7th ed. Hoboken, NJ: John Wiley\& Sons Publishers, 2009.

Bottomley, G. "Multiculturalism in practice: A study of Greek Australian families in Sydney." In Greeks in Australia edited by Karardis, G. and A.M. Tamis. Melbourne: River Seine Press, 1988.

Catarci, Marco. "Intercultural education in the European context: key marks from a comparative study." Intercultural Education 25, no. 2, (2014): 95-104.

Council Directive, Education of the children of migrant workers, 77/486/EEC, Official Journal of the European Communities L 199, \32-33, July 25, 1977. https://eur-lex.europa.eu/legal-content/EN/TXT/?uri=CELEX\%3A31977Lo486.

Council of Ministers of Education. "Council Conclusions of 25 May 2007 on a Coherent Framework of Indicators and Benchmarks for Monitoring Progress towards the Lisbon Objectives and Training." Brussels: Official Journal of the European Union C311/10, (2007).

Council of Ministers of Education. Green Paper on the European Dimension of Education. Luxembourg: Office for Official Publications on the European Communities, 1993.

Council of Ministers of Education. "Recommendation of the European Parliament and the Council of 18 December 2006 on Key Competencies for Lifelong Learning." Brussels: Official Journal of the European Union L 394/10, (2006).

Council of Ministers of Education. "Resolution of the Council and the Ministers of Education Meeting within the Council on the European Dimension in Education of 24 May 1988". Luxembourg: Official Journal of the European Communities C (177): 5-7. 
Council Resolution, 21 January 1974, Concerning a social action programme, Official Journal of the European Communities, No. C 13, ๆ1, 12.2.1974.

Damanakis, Michael. "European and Intercultural Dimension in Greek Education". European Educational Research Journal 4, no. 1, (2005): 79-88.

European Commission, EACEA and Eurydice. Citizenship Education at School in Europe - 2017. Eurydice Report. Luxembourg: Publications Office of the European Union, 2017.

Grossman, Jean Baldwin and Jean Rhodes. "The test of time: predictors and effects of duration in youth mentoring programs." American Journal of Community Psychology 30, (2002): 199-206.

Gundara, J.S. Interculturalism, Education and Inclusion. London: Paul Chapman, 2000.

Hansen, P. "Schooling a European identity: Ethnocultural exclusion and nationalist resonance within the EU policy of the European dimension of education," European Journal of Intercultural Studies 9, no.1, (1998): 5-23.

Herrera, Carla, Amy J. A. Arbreton, Cynthia L. Sipe, Sarah K. Pepper and Wendy S. McClanahan. Mentoring School-Age Children: Relationship Development in Community based and School based Programs. Philadelphia: Public/Private Ventures, 2000.

Faas, Daniel. 2011a."Between ethnocentrism and Europeanism? An exploration of the effects of migration and European integration on curricula and policies." Ethnocities, 11, no. 2, (2011): 163-183.

- 2011b. "The Nation, Europe and Migration: A comparison of geography, history and citizenship education curricula in Greece, Germany and England." Journal of Curriculum Studies 43, no. 4, (2011): 471-492.

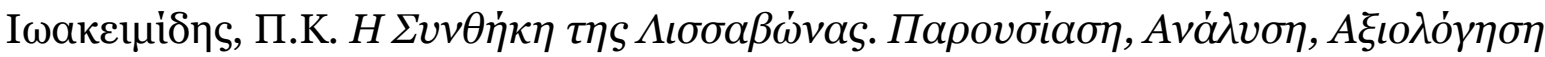

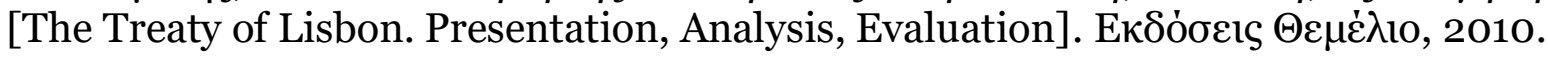

Kazamias, Andreas M. and Yiannis Roussakis. "Crisis and Reform in Greek Education.” European Education 35, no. 3, (2003): 7-30.

Kempa, A. and Zacny B. "The Curriculum Content Analysis for the Construction of the Teaching Process" Studies and Proceedings of Polish Association for Knowledge Management, no.6o, (2012): 97- 107.

Kitromilides, P., “Imagined Communities' and the Origins of the National Question in the Balkans." In Modern Greece: Nationalism and Nationality, edited by Blinkhorn, M. and T. Veremis, 25-33. Athens: ELIAMEP, 1990.

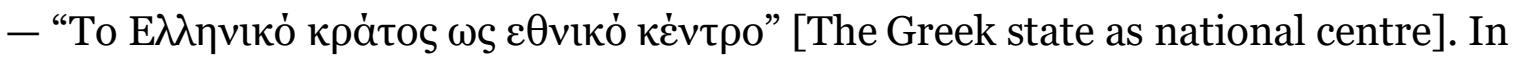
Hellenism and Greekness: Ideological and Biographical Axes of Modern Greek Society edited by Tsaoussis, D. Athens: Estia, 1983.

Kontogiannopoulou-Polydorides, Georgia, Kottoula, Mary and Dimopoulou, Kelly. "Citizen Education: Silencing Crucial issues." Journal of Modern Greek Studies 18, (2000): 287-303.

Markou, George. "Intercultural education in multicultural Greece”. European Journal of Intercultural Studies 4, no. 3, (1993): 32-43. 
Mattheou, Dimitris. National Report on the Implementation for the Socrates Programme in Greece, 200O- 2003. Laboratory for Comparative Education, International Educational Policy and Communication. National and Kapodistrian University of Athens, 2003.

Moschonas, Andreas. Education and Training in the European Union. Aldershot: Ashgate, 1998.

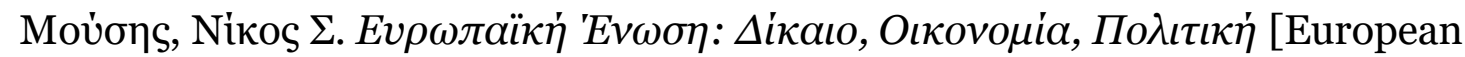

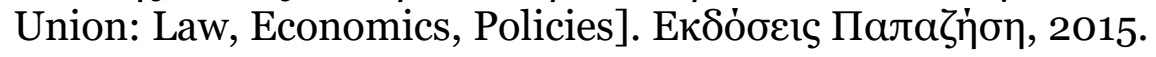

Official Government Gazette, Vol. ii 303/13-303

Paleologou, N. and O. Evangelou. Intercultural pedagogy. Educational, teaching and psychological approaches. Athina: Atrapos, 2003.

Palaiologou, N., and Daniel Faas. "How 'intercultural' is education in Greece? Insights from policymakers and educators." Compare: A Journal of Comparative and intercultural education 42, no. 4, (2012): 563-584.

Philippou, S. "Re-inventing Europe: the case of European dimension in Greek Cypriot geography and history curricula." The Curriculum Journal 18, no. 1, (2007): 57-88.

Schissler, H. and Y.N. Soysal, eds. The Nation, Europe and the World: Textbooks and Curricula in Transition. Oxford: Berghahn Books, 2005.

Smolicz, J.J. “National Policy on Languages: A community language perspective.” Australian Journal of Education 30, no. 1, (1986): 45-65.

Triandafyllidou, Anna and Gropas Ruby. "Greek Education Policy and the Challenges of Migration: An Intercultural View of Assimilation.” Paper prepared for the EMILIE project, ELIAMEP, November 2007. http://www.eliamep.gr/wpcontent/uploads/en/2008/10/greek_education_policy_and_the_challenge_of_mig ration_triandaf_and_gropas_emilie_wp3_22_nov_07.pdf.

- "Greek education policy and the challenge of migration: An 'intercultural' view of assimilation.” Race, Ethnicity and Education 14, no. 3, (2011): 399-419.

Tsoukalas, C. "Greek National identity in an integrated Europe and a Changing World Order.” In Greece, the New Europe and the Changing International Order, edited by Psomiades, H. and S.Thomadakis (New York: Pella).

Willis, P., R. Bland, L. Manka and C. Craft. "The ABC of peer mentoring - what secondary students have to say about cross-age peer mentoring in a regional Australian school." Educational Research and Evaluation 18, no. 2, (2012): 173-185. 